\title{
GENERAL REVIEW OF THE SURVEY'S ACTIVITIES IN 1966
}

The Geological Survey of Greenland continued in 1966 to carry out its three main tasks - the geological mapping of Greenland, the investigation of mineral deposits of economic interest and the publication of results. In addition the Survey has acted as geological adviser to the Ministry of Greenland in matters concerning the granting of mineral exploration concessions.

\section{Geological mapping}

Three categories of geological map are being prepared at present by the Survey:-

1) Regional maps at scales 1:500 000, 1:2500 000 and 1:5000 000 .

2) Survey map sheets at scale 1:100 000 .

3) Detailed maps of selected areas.

Regional maps

In response to a wish expressed by private business interests, work on regional maps of West Greenland at scale 1:500 000 was begun in 1964 and will be completed in 1968. Four sheets covering the ice-free area from Kap Farvel to Upernavik will then be ready for publication. As only five years have been allowed for field work and compilation, the maps in many inland areas will be based almost entirely on photo-geological interpretation. Field work on sheet III (see fig. 1) has been finished, and only very little remains to be done on sheet I. Mapping on sheets II and IV will be brought to an end in 1967-68.

Compilation of maps at 1:2 500 000 and 1:5000 000 is largely for the convenience of the organisations responsible for the preparation of the Geological Map of North America (1:10 000 000) and the Tectonic Map of Europe $(1: 2500$ 000).

Survey sheets at $1: 100000$

Map sheets at 1:100 000 are the main repository for the results of field mapping in Greenland. The first of the new series, Nunarssuit (see fig. 1) was printed in 1966, while the sheets Ivigtut, Mârmorilik, Nâgâtsiaq and Pangnertôq are completed in manuscript form. The sheets Agatdal, 
Qutdligssat, Julianehåb, Narssarssuaq and Nanortalik are being draughted. Field work on the sheets Neria and Midternæs is still in progress.

Special maps

Detailed maps to accompany Survey bulletins continue to be produced. Amongst such maps draughted during the past year those of the Igaliko syenite complex and the Akuliaruseq peninsula north of Nanortalik, may be mentioned.

Economic-geological investigations

Economic-geological investigations have been carried out on the chromite deposit at Fiskenæsset and on the beryllium, niobium and uranium occurrences near Narssaq. Apart from these special studies, records of mineralization have been kept in the course of the regional field mapping.

Chromite-rich layers in anorthosite horizons were discovered around Fiskenæsset in 1964, and in 1966 these were mapped in detail in selected localities. The extent of the chromite-bearing anorthosites was also mapped. The results of these investigations will be published shortly, and a brief review of the work is given by M. Ghisler in this report.

A radiometric survey has been made of the beryllium mineralization in the Ilímaussaq intrusion near Narssaq, South Greenland. This work is a continuation of earlier investigations and will be resumed in the coming season (see the account by J. Hansen in this report). The study of niobium and uranium mineralization in the Ilímaussaq rocks has been continued.

\section{Quaternary geology}

In conjunction with basement mapping, investigations in Quaternary deposits and glacial geology have been carried out. These have been primarily concerned with establishing the earlier positions of the Inland Ice margin and the related rise and subsidence of the land mass. In addition certain aspects of the extent and nature of permafrost have been studied.

\section{Collaboration with other institutes}

It is the policy of the Survey to maintain close contact with a large number of other institutions, both Danish and foreign, in order to benifit from the sharing of resources and the exchange of ideas. In keeping with this 


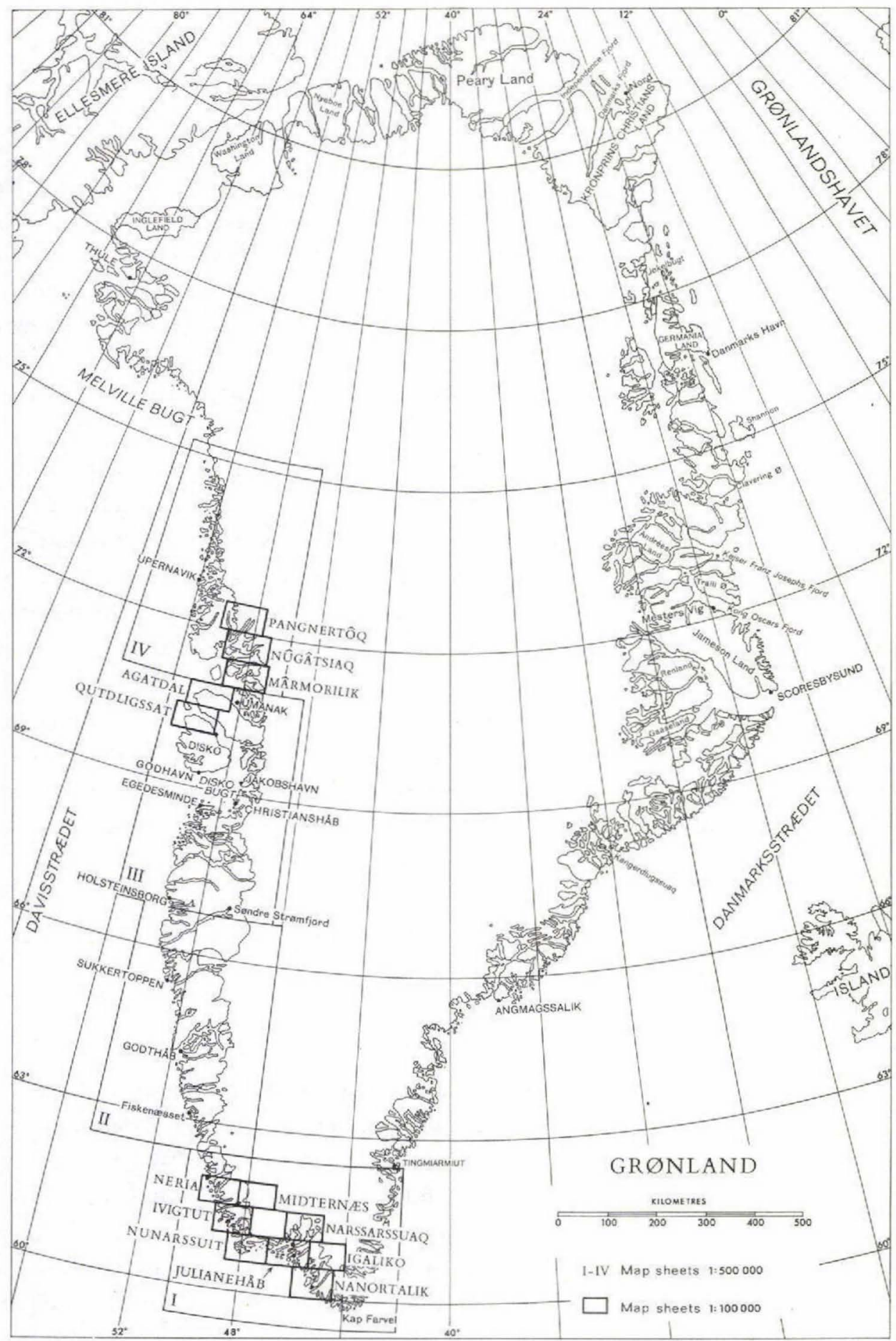


policy the Survey has in the past year collaborated with the MineralogicalGeological Museum of the University, Copenhagen, the Danish Atomic Energy Commission and the Geological Institute, Arhus University. Furthermore the Survey field team was joined in 1966 by geologists from the universities of London (Imperial College), Edinburgh, Durham, Exeter and Lancaster, and Portsmouth College of Technology in Great Britain, and from Charles University, Prague, and the University of Lausanne. A joint project in North Greenland was undertaken with the Geological Survey of Canada, the object being to obtain sufficient knowledge of the geology on either side of Robeson Channel to allow correlation across this channel.

Much of the work in Greenland forms not only part of the Survey mapping programme but also a contribution to various international research projects. As already mentioned in the International Union of Geological Sciences circular no. 12 , p. 58 (1964), the following current research can be considered as a contribution to the International Upper Mantle Project: study of the Gardar igneous province in South Greenland, compilation of generalized columnar sections for the Precambrian Ketilidian geosyncline of South Greenland and Karrat geosyncline of northern West Greenland, structural analysis of West Greenland, study of Tertiary volcanism in East and West Greenland. Furthermore a study of water balance and permafrost has been started in connection. with UNESCO's International Hydrological Decade. As already mentioned, the Survey has submitted maps for incorporation in the Geological Map of the World, and is also collaborating in the production of a Metallogenic Map of North America which will include Greenland.

Several foreign expeditions have visited Greenland during the summer, and the Survey has in many cases been in communication with the geologists in those parties.

Organisation and personnel

The permanent scientific staff of the Survey in 1966 consisted of 14 geologists and one chemist. During the field season this team was supplemented by 15 geologists from other institutions (see above) and 9 senior students. The permanent supporting staff in Copenhagen numbers 16; this figure is relatively low due to the sharing of many facilities with the University's Mineralogical-Geological Museum. The total number of participants (geologists and supporting staff) in the summer expedition was 87 together with 14 Greenlanders. 
Plans for 1967

It is planned to send approximately the same number of workers to Greenland in 1967 as was sent in 1966. The programme in West Greenland will follow the same pattern as in 1966, while new investigations in East Greenland are also being planned. Expeditions to Kap Stosch, Scoresby Sund and Angmagssalik are being considered.

K. Ellitsgaard-Rasmussen

Director 